\title{
Epilog: Implications for Public Policy
}

What then are the implications of these research findings reported in Masterpieces of Swiss Entrepreneurship? And for which communities might they be relevant?

The analysis in the previous 24 chapters captures the authors' findings based on their extensive field research regarding the practices of successful, export-based, and, mostly, long-lasting SMEs. Those findings are connected solely to the data from these companies. However, over the extended period of time that the authors worked on this project, it is only natural that additional thoughts going beyond the sample companies came to mind.

These observations primarily concern the relevant implications for public policy and the business community at large, which move beyond the defined professional research scope. The observations accrued alongside the detailed company research but are intended for interested audiences in business, politics, education, media, and the larger society.

The authors believe it worthwhile to communicate these observations in the form of a working list rather than to formulate them as a complete chapter, or essay, which would need to take into account the entire social context, something which could easily exceed the scope of a chapter, as well as the competence of the authors.

The observations are not meant to be exhaustive; the authors hope that readers will add their own thoughts and ideas for future considerations beyond those offered here.

The list of ideas that follows is structured around communities of interest. Again, this list is not meant to be a policy recommendation, but rather a thought-provoking exercise encouraging the impulse to consider the question "And now what?" 


\section{Observations for Business and Managerial Community}

- For Entrepreneurs and SME Managers

- In addition to having the "Big Idea," the mode of financing the enterprise needs equal attention.

- There is value in ramping up slowly, relying on one's own resources, however limited they may be.

- Discovering neglected projects and assets in larger corporations might provide value.

- Remaining close to the core technology of the venture brings long-term benefits.

- Stay true to your focus and avoid going into markets just because they seem more glamorous.

- For Corporate Managers at Large Companies

- Smaller units often do not receive sufficient attention from corporate management.

- Significant value can be unlocked if smaller units are given more freedom of operation.

- Operating Freedom vs. Independence: They are not the same; the former is more important for success.

- Smaller, maybe overlooked, units that could benefit from a greater willingness to divest to managers.

- For Owners of SMEs

- Owners need to grant professional management sufficient freedom of operation.

- When small, it helps if owners are technologically involved and can take the lead in development.

- Owners need to consider transferring ownership to professional management when encountering diminished entrepreneurial energy.

- Selling ownership to the highest bidder (trade sale) is not always beneficial to SME culture and future perspectives of business.

- Stability in ownership can take various forms, from single ownership to a larger group of shareholders.

- Connect the next generation of owners to the business at an early age.

\section{Observations for the Entrepreneurial Community}

- For Future Start-ups and Aspiring Entrepreneurs

- There is no age limit to becoming an entrepreneur.

- Frugal and small ramp-up appears to be typical for many businesses.

- Ideas for new businesses probably come from your existing business environment and experience: Look around. 
- Understanding the technology of the relevant market is crucial.

- Neglected businesses can be a good start for new owners to embark on their own business.

- Wherever you work, always ask the question: Can this be done better, and: Can it spawn a business?

- Opportunities are out there: You have to spot them and then capture them.

- Start with your means: What you know, what you have, and who you know.

- If you believe in your idea, get started even when resources are limited.

- Inventors looking for companies to commercialize ideas should pursue smaller SMEs because they are more flexible in terms of adopting new ideas.

\section{Observations for Financial Community}

- For Bankers and Lenders

- Smaller SMEs do not seem to like to depend on bank lending, since lenders have acquired a reputation for unreliability.

- Bank lending to SMEs is typically preferred for SME mortgages only.

- Larger SMEs are interested in obtaining financial support in case of major acquisitions.

- Increased support for MBOs of small company units at larger corporations enable existing management to become owners.

- For Investors

- Investors need to take a long-term view of their SME investments.

- Financial investors in SMEs have a role to play as long as they are willing to grant company management considerable operational freedom.

- Team and technology are two key factors to consider when investing.

- Investors need to invest time and resources to understand and appreciate technology development in the company they target.

\section{Observations for Consultants and Advisors}

- Few SMEs rely on consultants for their business decisions.

- Technical expertise is at times hired on a consultancy basis.

- Having consulting experience can be helpful for jumping into an SME leadership/ ownership role. However, affinity to the core technology of the company is required. 


\section{Observations for the Educational Community}

- General Recommendations for All Levels

- Promote business acumen, defined as the business, financial and economic parameters of any business. The term business acumen is used here in the sense of understanding: What is a business? How does it function? What are the financial parameters? It is different from a mere technical understanding of a business.

- Teaching about entrepreneurship should be included in curricula at all levels, adjusted to school type and student age.

- Understanding the SME environment and its opportunities is important and not only talking about the large companies that everyone knows.

- Teaching

- Foster the development of practice-based material for entrepreneurial mindset and business acumen for all educational levels.

- Include walking a factory floor with students into course curricula.

- Secondary Level

- Concentrate on the basics of business acumen: How does a business work?

- Middle School (up to Maturity)

- Economic history.

- History of entrepreneurship in Switzerland.

- Apprenticeship Level

- Teaching business acumen.

- Teaching entrepreneurial concepts.

- How to start your own operation, becoming economically independent-how to become a Company of One and beyond.

- Open up apprenticeship programs for maturity graduates, and shorter versions for university graduates.

- Appreciation of the technical skills as the basis for a business.

- Universities of Applied Sciences

- Business Programs

Teaching of entrepreneurial concepts

- Technical Programs

Teaching of entrepreneurial concepts

Teaching of entrepreneurship competencies and practices (Entrepreneurship Toolbox)

- Universities and Institutes

- Technical (ETH Zurich, EPF Lausanne)

History of entrepreneurial contributions to Switzerland.

Teaching of entrepreneurial concepts and practices.

Business and economic acumen. 
- Business Programs

History of entrepreneurial contributions to Switzerland

Readiness to take on entrepreneurial roles at all professional levels and ages.

Teaching of entrepreneurship for SMEs (Entrepreneurship Toolbox).

\section{Observations for Political and Governmental Community/Public Policy}

- Policy Areas

- Promote not just start-ups but also SME continuation.

- Policy actors shaping public policy should acquire business acumen, to be able to engage with SME community.

- Focus on policies that favor maintaining ownership of companies with founders/families:

Facilitating transition from one generation of owners to another (fiscal policies).

Making MBOs or similar moves (more) affordable to employees and management (fiscal policies).

- Ensure rural accessibility of SME sites through infrastructure support, for example, public transport, telecommunications, and infrastructure, expanding the hiring pool radius.

- Strengthen attractiveness of apprenticeship programs and promote value of dual educational pathways.

- Ensure high-quality standards for teaching personnel at all levels.

\section{Observations for Members of the Media}

- Show that entrepreneurship is not just for Silicon Valley; it can take place everywhere, every day.

- A stronger understanding of business and entrepreneurial endeavors in society is needed.

- Entrepreneurial achievements could be more visible in society.

- Increased coverage of the history of SME contributions to Switzerland.

- Share the stories about the daily life of SMEs, and celebrate their achievements. 


\section{Observations for Society at Large and Individual Citizens}

- Curiosity and tolerance of entrepreneurial endeavors.

- Acceptance of the entrepreneurial success of others.

- Nurturing a can-do spirit where people can trial their idea at minimal cost and learn from failure.

- Celebrating entrepreneurial effort and success.

- Entrepreneurial failure should not become a social stigma.

- Raising the entrepreneurial profile-moving from employee thinking to an entrepreneurial "copreneur" attitude with proactive thinking, and open to ownership initiatives.

- Investing in effort and training to prepare for becoming a manager or owner.

Open Access This chapter is licensed under the terms of the Creative Commons Attribution 4.0 International License (http://creativecommons.org/licenses/by/4.0/), which permits use, sharing, adaptation, distribution and reproduction in any medium or format, as long as you give appropriate credit to the original author(s) and the source, provide a link to the Creative Commons license and indicate if changes were made.

The images or other third party material in this chapter are included in the chapter's Creative Commons license, unless indicated otherwise in a credit line to the material. If material is not included in the chapter's Creative Commons license and your intended use is not permitted by statutory regulation or exceeds the permitted use, you will need to obtain permission directly from the copyright holder.

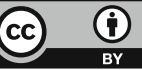

